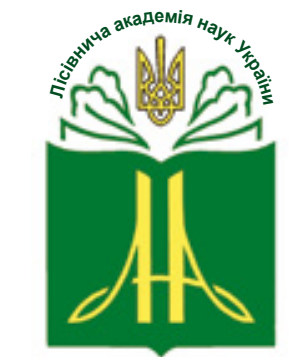

Forestry Academy of Sciences of Ukraine

Наукові праці Лісівничої академії наук України Proceedings of the Forestry Academy of Sciences of Ukraine

http://fasu.nltu.edu.ua

https://doi.org/10.15421/411935

Article received 2019.06.24

Article accepted 2019.12.26
ISSN 1991-606X print

ISSN 2616-5015 online

(a) $\square$ Correspondence author

Viktor Myroniuk

victor.myroniuk@nubip.edu.ua

Heroiv Oborony st., 15, Kyiv, 03041, Ukraine

УДК 630.53

\title{
Дешифрування видового складу лісових насаджень за даними сезонних мозаїк супутникових знімків Landsat і вибіркової інвентаризації лісів
}

\author{
В. В. Миронюк'
}

Дешифрування видового складу лісових насаджень за супутниковими знімками має важливе значення для оцінювання стану та динаміки лісових ресурсів. У роботі використано часові ряди знімків Landsat 8 OLI, а як джерело опорної інформаџї-дані регіональної інвентаризаиії лісів Сумської області 2013 р., отримані на 333 кругових пробних ділянках. Супутникові знімки відібрано для часового періоду 2014-2016 рр. та скомпоновано в безхмарні мозаїки для трьох сезонів: квітень-жовтень, літо, осінь. Для дешифрування поширення деревостанів різного видового складу, а також деревних видів, які домінують у складі насаджень, на основі методу $k$ найближчих сусідів (k-NN) спрогнозовано значення сум площ перерізів восьми найбільш представлених у лісовому фонді області видів. У дослідженні використано алгоритм k-NN методу, адаптований до платформи хмарних обчислень Google Earth Engine. Як міру пошуку найближчих сусідів застосовано Евклідову відстань у просторі спектральних показників супутникових знімків Landsat і допоміжної неспектральної інформації. За результатами досліджень отримано неперервні попіксельні оцінки сум плош перерізів деревостанів сосни, дуба, клена, липи, берези, ясена, осики та вільхи. На основі отриманих карт встановлено поширення основних лісотвірних деревних видів Сумської області, а за очінками сум площ перерізів створено карту деревних видів, які домінують у насадженнях. На основі порівняння розподілу площі деревостанів за деревними видами, щчо домінують у насадженнях, встановлено узгодженість у відсотковому співвідношенні оцінок із офіціииними даними обліку лісів області. На основі виконаних досліджень визначено актуальним запровадження в інвентаризацію лісів Украӥни методів дистанційного зондування Землі.

Ключові слова: класифікація; метод найближчих сусідів; хмарні обчислення; облік лісів; моніторинг; вибірка; часовий ряд; сума площч перерізів.

Вступ. Наявність чітких у просторовому вимірі даних про поширення видів деревної рослинності відіграє вагому роль у розумінні динаміки лісового покриву, а також сприяє запровадженню ефективного екологічно орієнтованого лісового менеджменту. Згідно з висновками літературного огляду публікацій (Fassnacht et al., 2016), з початку 1980-х років простежується тренд до зростання кількості нау- кових досліджень видового складу лісів методами дистанційного зондування Землі (ДЗ3). Незважаючи на вагомі успіхи в цьому напрямі, розпізнавання деревних видів за супутниковими знімками залишається складним завданням, оскільки внутрішньовидова варіація спектральних показників зазвичай перевищує міжвидову (Hill, Wilson, George, \& Hinsley, 2010). Значні обмеження багатьох методів

Миронюк Віктор Валентинович - член-кореспондент Лісівничої академії наук України, доцент кафедри таксації лісу та лісового менеджменту, доктор сільськогосподарських наук. Національний університет біоресурсів і природокористування України, вул. Героїв Оборони, 15, м. Київ, 03041, Україна. Тел.: +38-044-527-85-23. E-mail: victor.myroniuk@nubip.edu.ua ORCID: https://orcid.org/00000002-5961-300X 
Д33 пов'язані зі складною просторовою структурою лісових насаджень, за якої на знімках простежується тільки верхній ярус насадження (Immitzer, Atzberger, \& Koukal, 2012). 3 огляду на це, особливу увагу приділяють дослідженню сезонної мінливості їхніх спектральних показників упродовж року, які пов'язані з фенологічним станом рослинності та біофізичними параметрами деревного намету (Myroniuk, 2017a).

Для дешифрування видового складу насаджень важливе значення має вибір сезону знімання. За даними Hill et al. (2010), знімки, зроблені впродовж осіннього сезону, є інформативнішими, ніж літні та весняні, а поєднання їх у вигляді часового ряду забезпечує найвищу точність класифікації. Дослідження, виконані на основі комерційних сенсорів RapidEye i Formosat-2, підтвердили ефективність розпізнавання деревних видів за мультиспектральними супутниковими знімками, одержаними в різні періоди одного вегетаційного сезону (Sheeren et al., 2016; Tigges, Lakes, \& Hostert, 2013). У сучасних умовах під час масштабних досліджень лісового покриву для цього широко застосовують безоплатні дані сенсорів Landsat (Thompson, Nelson, White, \& Wulder, 2015) та Sentinel 2 (Hościło \& Lewandowska, 2019). Їхня перевага полягає в можливості підібрати знімки високої якості для обраної області інтересу, тоді як пропуски інформації внаслідок хмарності територій можуть бути компенсовані даними інших знімків, близьких у часовому діапазоні (Zhu \& Liu, 2014). На думку Hansen \& Loveland (2012), у майбутньому більшість методів моніторингу будуть побудовані на основі часових серій супутникових знімків, а не окремих сцен, що змістить акцент досліджень на грунтовнішому аналізі даних на рівні окремого пікселя. Завдяки повторювальним спостереженням з'являється можливість відібрати 3 часової серії так звані «найкращі пікселі», відповідно до встановлених критеріїв: сезону знімання, хмарності тощо (White et al., 2014).

Як зазначають Hościło \& Lewandowska (2019), крім застосування методів аналізу часових рядів супутникових спостережень, важливе значення для дешифрування видового складу лісових насаджень має якість наземних даних. Найточнішою вважають інформацію, отриману під час обліку лісів вибірковими методами. 3 огляду на це, дешифрування видового складу стало однією з ключових ідей методології сучасної статистичної інвентаризації лісів (Franco-Lopez, Ek, \& Bauer, 2001, Trubins \& Sallnäs, 2014). Зокрема, шведські вчені Reese et al. (2002) звернули увагу, що на основі оптичних супутникових даних і методу $k$ найближчих сусідів $(k-\mathrm{NN})$ методу вдається здійснити дешифрування насаджень із домінуванням хвойних і листяних видів з відхиленням не більше $10 \%$. Використовуючи канонічний аналіз відповідності, багато авторів (Ohmann \& Gregory, 2002, Ohmann, Gregory, Henderson, \& Roberts, 2011) довели ефективність $k$-NN алгоритму для дешифрування просторового градієнта поширення низки деревних видів у гірських регіонах штату Орегон, США. Загалом методичні підходи, які розробили вчені Північно-Західного Тихоокенського регіону США, становлять значний науковий інтерес для дешифрування видового складу лісових насаджень за $k$-NN методом (Henderson, Ohmann, Gregory, Roberts, \& Zald, 2014, Hudak, Crookston, Evans, Hall, \& Falkowski, 2008, Ohmann, Gregory, \& Roberts, 2014, Ohmann et al., 2012). При цьому $k$-NN метод $\epsilon$ ефективною технологією дешифрування знімків, апробований у різних природних зонах планети та засвідчив свою універсальність у контексті спільної обробки даних вибіркової інвентаризації лісів і супутникового знімання (Chirici et al., 2016). У цій роботі його застосовано для дешифрування видового складу лісів на основі даних вибіркової інвентаризації лісів Сумської області та часових рядів супутникових знімків Landsat 8 OLI.

Актуальність теми дослідження пов'язана 3 необхідністю вдосконалення методичного базису національної інвентаризації лісів України, який повинен відповідати сучасним світовим тенденціям обліку лісів. 3 огляду на це, у роботі обгрунтовано технологію поєднання наземних вибіркових даних, безоплатних мультиспектральних супутникових знімків Landsat та хмарних технологій для аналізу значного обсягу інформації, картографування та визначення площі лісових насаджень Сумської області різного видового складу.

Об'скти та методика досліджень. Об 'єкт дослідження - лісові насадження Сумської області, в яких Центр національної інвентаризації лісів України впродовж 2008-2015 pр. проводив регіональну вибірково-статистичну інвентаризацію. Предмет дослідження - видовий склад лісових насаджень i методи його дешифрування за даними мультиспектрального супутникового знімання. Мета роботи полягає в опрацюванні методики дешифрування видового складу лісових насаджень на основі даних вибіркової інвентаризації лісів та часових рядів супутникових знімків Landsat.

Дані вибіркової інвентаризаиї лісів. Дослідний матеріал формують дані таксації лісових насаджень Сумської області на 333 кругових пробних ділянках площею $500 \mathrm{~m}^{2}$, які зібрано впродовж 2013 р. під час другого циклу інвентаризації. Просторову основу досліджень формує вибірковий дизайн національної інвентаризації лісів України 3 регулярною мережею вибіркових одиниць (квадрат зі стороною $2,7 \times 2,7$ км). У межах кожної 3 них випадково розміщено кластер із чотирьох кругових пробних площ, розташованих у вершинах квадрата зі стороною 420 м. На пробних ділянках виконували обмір дерев завтовшки понад $8 \mathrm{~cm}$, на основі чого обчислено суму площ перерізів дерев кожного деревного виду на 1 га. Наявний дослідний матеріал дав змогу сконцентрувати увагу на восьми деревних видах, що домінують на території дослідження: Pinus sylvestris L., Querqus robur L., Acer platanoides L., Tilia cordata Mill., Betula pendula Roth., Fraxinus excelsior L., Populus tremula L. Ta Alnus glutinosa (L.) Gaerth. 
Метод к найближчих сусідів. Дешифрування видового складу виконували на основі методу $k$ найближчих сусідів (McRoberts \& Tomppo, 2007) за прогнозними значеннями сум площ перерізів дерев у насадженні. Такий підхід дав змогу максимально узгодити встановлення видового складу лісових насаджень дистанційними та наземними методами. Вибір налаштування алгоритму виконано відповідно до результатів опублікованих раніше досліджень (Myroniuk, Bilous, \& Diachuk, 2019), які рекомендують: 1) використовувати Евклідову відстань для пошуку найближчих сусідів; 2) виконувати пошук одного $(k=1)$ найближчого сусіда; 3$)$ застосовувати часові ряди супутникових спостережень. Алгоритм дешифрування опрацьовано на базі сучасної платформи для хмарних обчислень Google Earth Engine (GEE), яка одночасно забезпечує доступ до даних Д33 та ефективне оброблення супутникових знімків в одному із найпотужніших комп'ютерних кластерів (Gorelick et al., 2017).

Сезонні мозаїки Landsat 8 OLI. Для території досліджень підготовлено безхмарні мозаїки зі знімків Landsat 8 OLI рівня обробки L1TP (орторектифіковані дані, приведені до значень відбиття на сенсорі) для трьох сезонів: квітень-жовтень, літо, осінь. Для створення мозаїк відбирали знімки для періоду 2014-2016 pp. 3 хмарністю менше 30\%. Після за- стосування маски хмар для літньої та осінньої мозаїк знімки поканально поєднували за принципом відбору тих пікселів, які мали найбільші значення індексу NDVI. Використаний алгоритм відразу дав змогу зменшити розмірність даних і позбутися впливу хмар і тіней від них на якість спектральної інформації. Мозаїку для періоду квітень-жовтень, яка характеризує сезон вегетації рослинності, створено теж після маскування хмар, однак відбираючи 1-й, 3-й квартилі та медіану значень пікселів у часовому ряді знімків цього періоду. Для дешифрування використано дані спектральних каналів видимого червоного, ближнього та короткохвильового інфрачервоного спектрів (канали 4-7), їхні співвідношення, вегетаційний індекс NDVI, три канали ортогонального перетворення типу Tasseled-Cap (ТCT), які доповнювали неспектральними показниками, зокрема, географічними координатами широти та довготи, висоти над рівнем моря та індексом топографічного положення (Weiss, 2001). Загалом для дешифрування використано 38 показників (Myroniuk, 2017b).

На основі запропонованої методики (рис. 1) у роботі розглядаємо дві задачі: 1) картографування поширення деревних видів на території досліджень; 2) дешифрування лісових насаджень за деревними видами, які домінують.

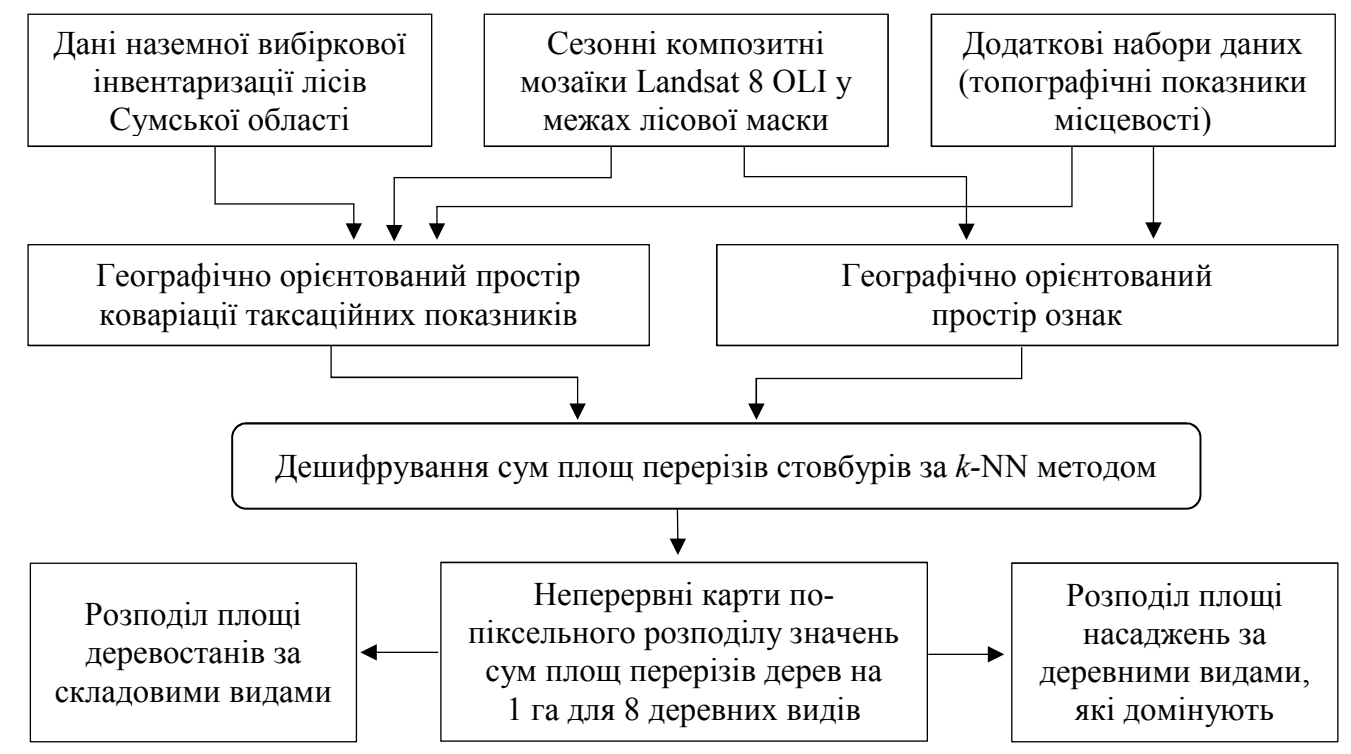

Рис. 1. Блок-схема дешифрування видового складу лісових насаджень за даними супутникових знімків Landsat $8 \mathrm{OLI}$

Відповідно до $k$-NN методу значення сум площ перерізів деревостанів, встановлені на кожній вибірковій одиниці, поєднані зі спектральними та додатковими неспектральними показниками, формують простір коваріачіï. Багатовимірний простір ознак складається лише 3 даних спектральних каналів супутникових знімків і топографічних показників місцевості, встановлених для кожного пікселя знімків. Завдяки спільній географічній прив'язці, обидва простори можуть поєднуватися. При цьому утворюється масив, що містить пропуски даних відсутні наземні спостереження для значної частини елементів (пікселів супутникових знімків). Ці пропуски заповнюють значеннями таксаційних показників простору коваріації, які у просторі ознак найближчі. Результатом оброблення даних $є$ тематичні карти, що відображають розподіл сум площ перерізів за деревними видами. Ці карти застосовують для встановлення поширення насаджень різного видового складу. 
Результати та обговорення. Дослідження поширення та видового складу лісових насаджень $€$ ключовим завданням методів дистанційного зондування лісів. Наразі існує декілька підходів стосовно картографування видового складу лісових насаджень: 1) бінарний прогноз наявності чи відсутності конкретного деревного виду; 2) відображення значень сум площ перерізів певного деревного виду на одиниці площі у вигляді неперервних шкал; 3) відтворення неперервного розподілу загальної суми площ поперечних перерізів усіх елементів лісу на одиниці площі (Henderson et al., 2014). Точність прогнозування за першими двома способами залежить від кількості елементів лісу насаджень та форми деревостанів.

Як відомо, формула складу лісових насаджень визначається за співвідношенням запасів або сум площ перерізів деревостану. Задля узгодження методичних прийомів наземних і дистанційних вимірювань на основі $k$-NN методу спрогнозовано розподіл сум площ поперечних перерізів восьми найпоширеніших деревних видів Сумської області. Створені карти відображають кількісну оцінку абсолютної повноти деревостанів і свідчать, що значення сум площ перерізів у перерахунку на 1 га достатньо варіюють. Найбільші значення характерні для деревостанів сосни звичайної, які на рівні окремого пікселя $30 \times 30$ м можуть сягати $50 \mathrm{~m}^{2} \cdot \mathrm{ra}^{-1}$ та більше.

Дешифрування видового складу лісів здійснювали в межах лісової маски Сумської області, опрацьованої за даними Landsat 8 OLI для всієї території рівнинної частини України (Myroniuk, 2018). Перевага $k$-NN методу полягає в можливості прогнозу- вання відразу декількох таксаційних показників на основі спільної матриці близькості до найближчих сусідів. У цьому дослідженні таку матрицю побудовано, використовуючи значення загальної суми площ перерізів дерев у насадженні. Після того як найближчий сусід для $i$-го пікселя 3-поміж даних простору коваріації встановлено, всі його атрибути (показники на пробі) приписано цьому пікселю. Унаслідок цього отримано вісім тематичних карт, які $є$ неперервними прогнозними оцінками сум площ перерізів восьми зазначених деревних видів. Порівнюючи їх попіксельно, встановлено деревні види, які домінують, а також їхню загальну кількість в одному пікселі.

Відповідно до отриманого прогнозу кількості елементів лісу за $k$-NN методом (рис. 2), на території дослідження переважають лісові насадження, у складі яких налічується три деревні види. Приблизно 1/4 деревостанів сосни звичайної чисті за складом, ще майже $1 / 2-3$ домішкою одного або двох елементів лісу. На відміну від цього, дуб звичайний, клен гостролистий, липа дрібнолиста та ясен звичайний практично ніколи не формують чистих деревостанів. Найчастіше вони ростуть у лісових насадженнях, до складу яких входить 3-5 супутніх видів. На основі наведених розподілів варто очікувати більшої невизначеності результатів моделювання сум площ перерізів, у складі яких налічується значна кількість елементів лісу. У просторовому вимірі помилки теж будуть розподілятися нерівномірно та залежатимуть від поширення цих насаджень на території Сумської області.

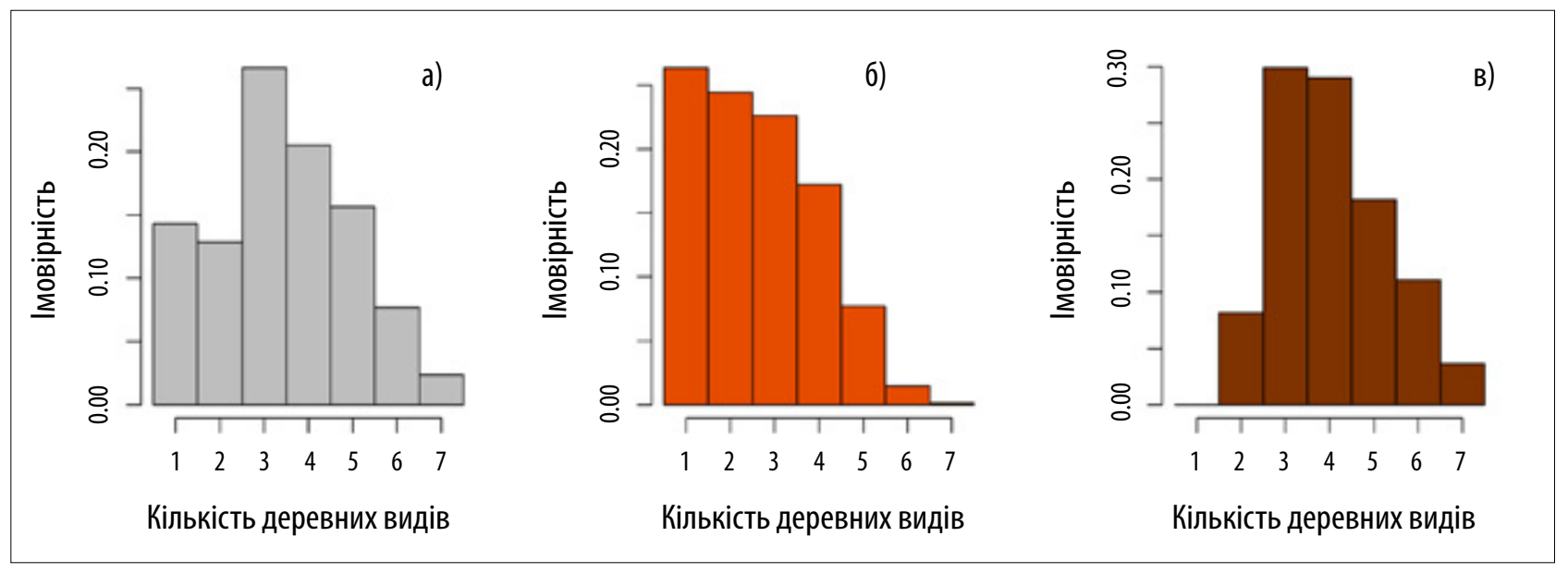

Рис. 2. Розподіл кількості деревних видів у складі лісових насаджень Сумської області за даними дешифрування супутникових знімків Landsat 8 OLI: а) загальний розподіл; б) насадження 3 домінуванням сосни звичайної; в) насадження $з$ домінуванням дуба звичайного

Найбільша видова різноманітність притаманна деревостанам, які ростуть переважно у південносхідній частині Сумської області. Це лісові насадження, утворені твердолистяними деревними видами - дубом звичайним, ясеном звичайним, кленом гостролистим. До їхнього складу досить часто входить липа дрібнолиста. На відміну від цього, північній частині Сумської області притаманна істотно менша видова різноманітність. Тут основну частину лісового фонду формують соснові деревостани. Отже, задля ефективного застосування методів дистанційного моніторингу лісів необхідно володіти достатньою інформацією про видовий склад лісів області. 
Отримані градієнти розподілу сум площ перерізів врешті-решт трансформовано в тематичну карту, що відображає поширення домінантних (за абсолютною повнотою) деревних видів (рис. 3).

Відповідно до рис. 3, на території Сумської області спостерігається специфічний розподіл площі лісових насаджень залежно від видового складу, який узгоджується з лісорослинним районуванням iï території. На півночі в поліській частині області ростуть лісові насадження, де домінує сосна звичайна. Тут значно меншу площу займають лісові насадження 3 домінуванням берези повислої та дуба звичайного, ще рідше трапляються деревостани, де головною породою є осика. У південному напрямку видове різноманіття насаджень істотно зростає, причому спостерігається зміна головних лісотвірних видів. У насадженнях лісостепової зони області домінують ясен звичайний, дуб звичайний і липа дрібнолиста. Все ж окремими великими масивами на півдні та південному заході ростуть лісові насадження 3 домінуванням сосни звичайної. Вільха клейка приурочена до понижених ділянок, що частіше розташовані у західній частині Сумської області.

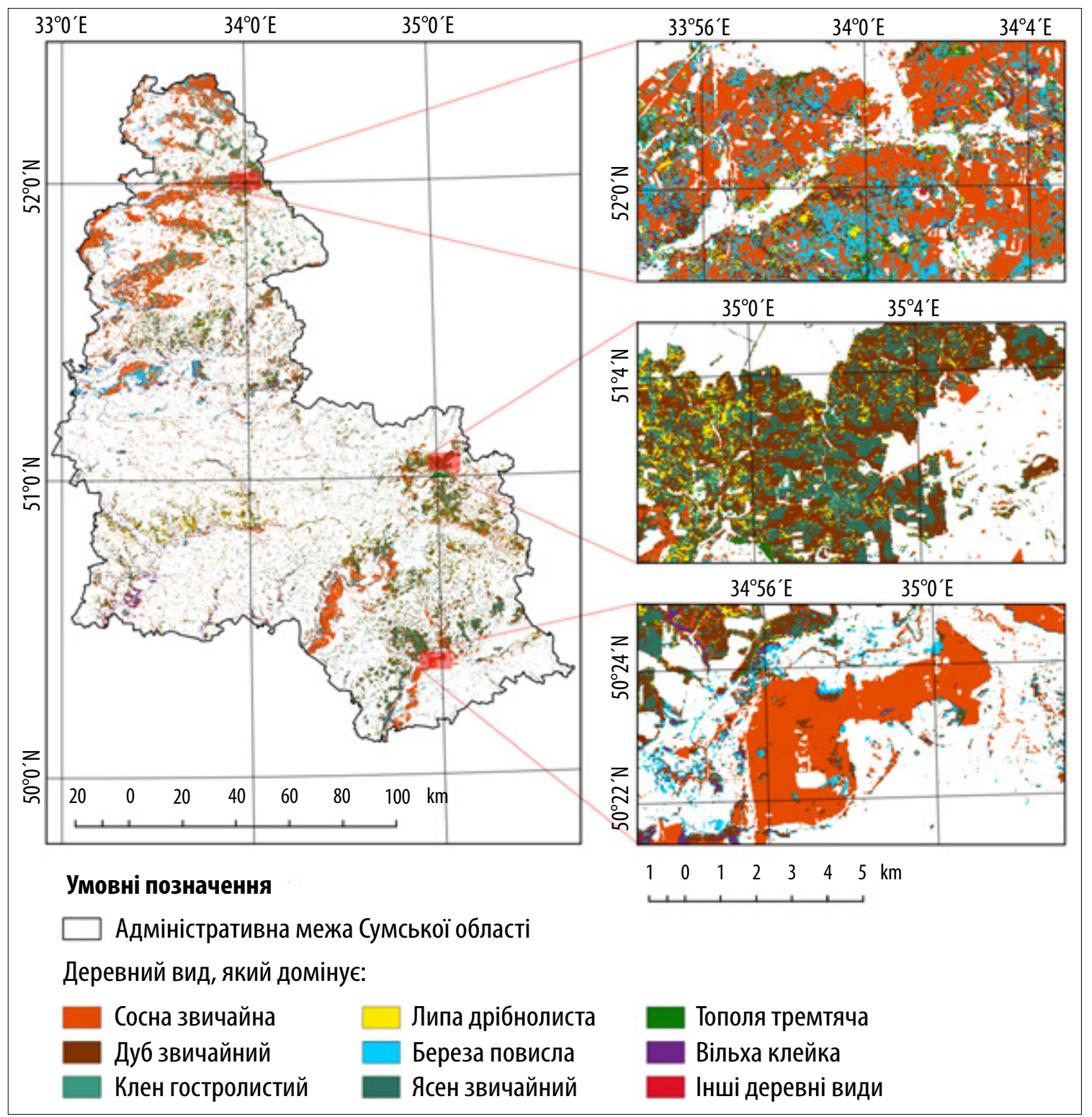

Рис. 3. Деревні види, які домінують у лісових насадженнях Сумської області, відповідно до даних дешифрування супутникових знімків Landsat 8 OLI на основі $k$-NN методу

У контексті ефективності дешифрування видового складу лісових насаджень варто звернути увагу на просторово-параметричну структуру лісових насаджень різного видового складу. За наявності складних за формою насаджень може бути більше помилок дешифрування, оскільки розпізнавання складу другого ярусу істотно погіршується. Проте, завдяки перевагам $k$-NN методу, який дає змогу відразу прогнозувати декілька показників лісових насаджень, зберігаються певні передумови для точнішого картографування лісів, порівняно 3 іншими методами. За умови коректного вибору найближчо- 
го сусіда, цільовому пікселю приписується весь набір таксаційних показників, встановлених на пробній ділянці. Таким способом з'являються підстави для дешифрування видового складу навіть складних за формою лісових насаджень, використовуючи мультиспектральні супутникові знімки оптичного діапазону.

Створена карта дала змогу встановити розподіл площі вкритих лісовою рослинністю ділянок за деревними видами, які домінують у лісовому фонді області (рис. 4). Для порівняння результатів використано відносні значення фактичного розподілу площ лісових насаджень за основними лісотвірними деревними видами, які одержали за повидільною базою даних про лісовий фонд області. Розподіли площі вкритих лісовою рослинністю ділянок за домінуючими деревними видами у відсотковому співвідношенні достатньо узгоджуються. Відповідно до прогностичного картографування відзначено певне перевищення площі соснових і дубових деревостанів, які переважають у структурі лісового фонду області. Це можна пояснити, з одного боку, помилками дешифрування, а 3 іншого - класифікацією лісових насаджень у практиці лісовпорядного проектування за головними породами.

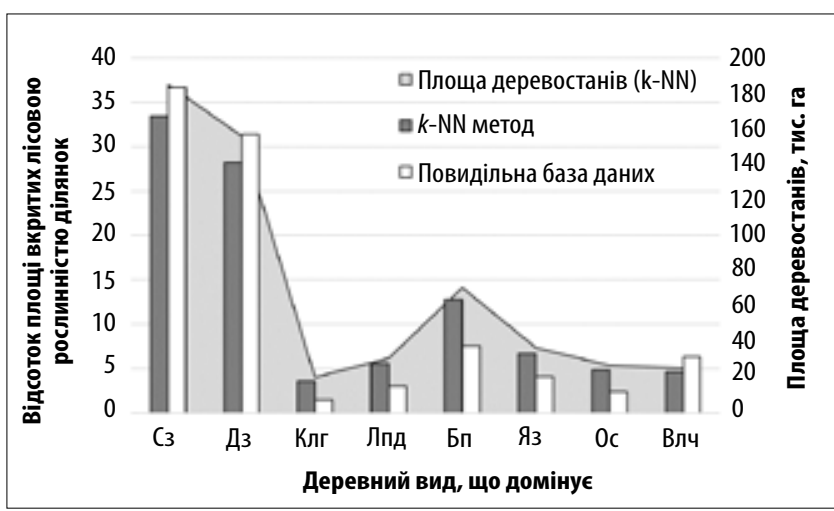

Рис. 4. Порівняння прогнозних і фактичних розподілів площі лісових насаджень за основними лісотвірними деревними видами (С3 - сосна звичайна, Дз - дуб звичайний, Клг - клен гостролистий, Лпд - липа дрібнолиста, Бп - береза повисла, Яз - ясен звичайний, Oc - тополя тремтяча, Влч - вільха клейка)

Запропонований метод дешифрування видового складу принципово відрізняється від наявних, оскільки дає змогу відобразити фактичну присутність певного деревного виду в насадженні. Він має важливе значення для обчислення запасу деревостанів за елементними лісу, що максимально наближує наземні та дистанційні методи обчислень. Загалом методика дешифрування видового складу лісових насаджень виконується найточніше 3 використанням наземних даних, які отримують під час вибіркових досліджень. Зазначене свідчить про необхідність подальшого розвитку національної інвентаризації лісів України, яка, крім забезпечення актуальними статистичними даними про показники лісового фонду, створює важливе наукове підгрунтя для детального картографування лісів України на основі методів Д33. 3 іншого боку, сучасна концепція розвитку методів обліку лісів повинна передбачити ширше застосування технологій дистанційного зондування Землі.

Висновки. Дешифрування видового складу лісових насаджень за даними супутникового знімання дає змогу ефективно отримувати інформацію про стан лісових насаджень для завдань моніторингу лісів різного масштабу. Водночас сучасні технології Д33 розширюють завдання статистичної інвентаризації лісів. За результатами виконаних досліджень можна сформулювати три ключові узагальнення: a) поєднання часових рядів мультиспектральних супутникових знімків і даних вибіркової інвентаризації лісів забезпечує розробку карт видового складу лісових насаджень, які можуть застосовуватися в моніторингу лісових ресурсів; б) технології хмарних обчислень на базі платформи Google Earth Engine $\epsilon$ ефективним інструментом опрацювання великих масивів спектральних даних супутникових знімків; в) залежно від задач на основі даних Д33 можна отримати дискретні або неперервні карти поширення насаджень різного видового складу.

Подяка. Автор висловлює подяку Віталію Сторожуку за надання доступу до даних вибіркової інвентаризації лісів Сумської області за 2013 рік.

\section{References}

Chirici, G., Mura, M., McInerney, D., Py, N., Tomppo, E.O., Waser, L.T., ... McRoberts, R.E. (2016). A meta-analysis and review of the literature on the k-Nearest Neighbors technique for forestry applications that use remotely sensed data. Remote Sensing of Environment, 176, 282-294. https://doi. org/10.1016/j.rse.2016.02.001

Fassnacht, F.E., Latifi, H., Stereńczak, K., Modzelewska, A., Lefsky, M., Waser, L.T., ... Ghosh, A. (2016). Review of studies on tree species classification from remotely sensed data. Remote Sensing of Environment, 186, 64-87. https://doi. org/10.1016/j.rse.2016.08.013

Franco-Lopez, H., Ek, A.R., \& Bauer, M.E. (2001). Estimation and mapping of forest stand density, volume, and cover type using the k-nearest neighbors method. Remote Sensing of Environment, 77(3), 251-274. https://doi.org/10.1016/S00344257(01)00209-7

Gorelick, N., Hancher, M., Dixon, M., Ilyushchenko, S., Thau, D., \& Moore, R. (2017). Google Earth Engine: Planetary-scale geospatial analysis for everyone. Remote Sensing of Environment, 202, 18-27. https:// doi.org/10.1016/j.rse.2017.06.031

Hansen, M.C., \& Loveland, T. R. (2012). A review of large area monitoring of land cover change using Landsat data. Remote Sensing of Environment, 122, 66-74. https://doi.org/10.1016/j.rse.2011.08.024

Henderson, E.B., Ohmann, J.L., Gregory, M.J., Roberts, H.M., \& Zald, H. (2014). Species distribution modelling for plant communities: 
Stacked single species or multivariate modelling approaches? Applied Vegetation Science, 17(3), 516527. https://doi.org/10.1111/avsc. 12085

Hill, R.A., Wilson, A.K., George, M., \& Hinsley, S.A. (2010). Mapping tree species in temperate deciduous woodland using time-series multi-spectral data. Applied Vegetation Science, 13 (1), 86-99. https:// doi.org/10.1111/j.1654-109X.2009.01053.x

Hościło, A., \& Lewandowska, A. (2019). Mapping Forest Type and Tree Species on a Regional Scale Using Multi-Temporal Sentinel-2 Data. Remote Sensing, 11 (8), 929. https://doi.org/10.3390/ rs 11080929

Hudak, A. T., Crookston, N. L., Evans, J. S., Hall, D.E., \& Falkowski, M.J. (2008). Nearest neighbor imputation of species-level, plot-scale forest structure attributes from LiDAR data. Remote Sensing of Environment, 112 (5), 2232-2245. https:// doi.org/10.1016/j.rse.2007.10.009

Immitzer, M., Atzberger, C., \& Koukal, T. (2012). Tree Species Classification with Random Forest Using Very High Spatial Resolution 8-Band WorldView-2 Satellite Data. Remote Sensing, 4 (9), 2661-2693. https://doi.org/10.3390/rs4092661

McRoberts, R.E., \& Tomppo, E. (2007). Remote sensing support for national forest inventories. Remote Sensing of Environment, 110 (4), 412-419. https://doi.org/10.1016/j.rse.2006.09.034

Myroniuk, V. (2017a). Seasonal dynamics of spectral reflectance of land covers and its role in mapping forest stands using landsat images. Scientific Bulletin of National University of Life and Environmental Sciences of Ukraine, 266, 54-64. http://journals. nubip.edu.ua/index.php/Lisivnytstvo/article/ view/10543 (in Ukrainian).

Myroniuk, V. (2017b). Variable selection in the context of forest cover mapping using seasonal Landsat mosaics. Scientific Data, 278, 66-76. http://journals. nubip.edu.ua/index.php/Lisivnytstvo/article/ view/11372 (in Ukrainian).

Myroniuk, V. (2018). Forest cover mapping using landsat-based seasonal composited mosaics. Scientific Bulletin of Ukrainian National Forestry University, 28 (1), 28-33. https://doi.org/10.15421/40280105 (in Ukrainian).

Myroniuk, V., Bilous, A., \& Diachuk, P. (2019). Predictng forest stand parameters using the $k$-NN approach. Ukrainian Journal of Forest and Wood Science, 10 (2), 51-63. http://dx.doi.org/10.31548/ forest2019.02.051 (in Ukrainian).

Ohmann, J.L., \& Gregory, M.J. (2002). Predictive mapping of forest composition and structure with direct gradient analysis and nearest - neighbor imputation in coastal Oregon, U.S.A. Canadian Journal of Forest Research, 32 (4), 725-741. https:// doi.org/10.1139/x02-011

Ohmann, J.L., Gregory, M.J., Henderson, E.B., \& Roberts, H.M. (2011). Mapping gradients of community composition with nearest-neighbour imputation: Extending plot data for landscape analysis: Extending plot data for landscape analysis. Journal of Vegetation Science, 22 (4), 660-676. https://doi.org/10.1111/j.1654-1103.2010.01244.x

Ohmann, J. L., Gregory, M. J., \& Roberts, H. M. (2014). Scale considerations for integrating forest inventory plot data and satellite image data for regional forest mapping. Remote Sensing of Environment, 151, 3-15. https://doi.org/10.1016/j.rse.2013.08.048

Ohmann, J.L., Gregory, M.J., Roberts, H.M., Cohen, W.B., Kennedy, R.E., \& Yang, Z. (2012). Mapping change of older forest with nearestneighbor imputation and Landsat time-series. Forest Ecology and Management, 272, 13-25. https://doi. org/10.1016/j.foreco.2011.09.021

Reese, H., Nilsson, M., Sandström, P., \& Olsson, H. (2002). Applications using estimates of forest parameters derived from satellite and forest inventory data. Computers and Electronics in Agriculture, 37 (1-3), 37-55. https://doi.org/10.1016/S01681699(02)00118-7

Sheeren, D., Fauvel, M., Josipović, V., Lopes, M., Planque, C., Willm, J., \& Dejoux, J.-F. (2016). Tree Species Classification in Temperate Forests Using Formosat-2 Satellite Image Time Series. Remote Sensing, 8 (9), 734. https://doi.org/10.3390/ rs8090734

Thompson, S.D., Nelson, T.A., White, J.C., \& Wulder, M.A. (2015). Mapping Dominant Tree Species over Large Forested Areas Using Landsat Best-Available-Pixel Image Composites. Canadian Journal of Remote Sensing, 41 (3), 203-218. https:// doi.org/10.1080/07038992.2015.1065708

Tigges, J., Lakes, T., \& Hostert, P. (2013). Urban vegetation classification: Benefits of multitemporal RapidEye satellite data. Remote Sensing of Environment, 136, 66-75. https://doi.org/10.1016/j. rse.2013.05.001

Trubins, R., \& Sallnäs, O. (2014). Categorical mapping from estimates of continuous forest attributes classification and accuracy. Silva Fennica, 48 (2). https://doi.org/10.14214/sf.975

Weiss, A. (2001). Topographic Position and Landforms Analysis. Poster presentation presented at the ESRI User Conference, San Diego, CA.

White, J. C., Wulder, M.A., Hobart, G. W., Luther, J.E., Hermosilla, T., Griffiths, P., ... Guindon, L. (2014). Pixel-Based Image Compositing for Large-Area Dense Time Series Applications and Science. Canadian Journal of Remote Sensing, 40 (3), 192212. https://doi.org/10.1080/07038992.2014.945827

Zhu, X., \& Liu, D. (2014). Accurate mapping of forest types using dense seasonal Landsat timeseries. ISPRS Journal of Photogrammetry and Remote Sensing, 96, 1-11. https://doi.org/10.1016/j. isprsjprs.2014.06.012 


\section{Дешифрирование видового состава лесных насаждений за данными мозаик спутниковых снимков Landsat и выборочной инвентаризации лесов}

\section{В.В. Миронюк ${ }^{1}$}

Дешифрирование видового состава лесных насаждений по спутниковым снимкам имеет важное значение для оценки состояния и динамики лесных ресурсов. Большинство современных исследований указывает на эффективность картирования распространения древесных видов по временным сериям спутниковых наблюдений в сочетании с данными выборочной инвентаризации лесов. Для дешифрирования видового состава древостоев в работе использованы временные ряды снимков Landsat 8 OLI, а как источник опорной информации - данные региональной инвентаризации лесов Сумской области 2013 г. На основании замеров деревьев на 333 круговых пробных участках установлены суммы площадей сечений восьми самых распространенных в лесных насаждениях видов - Pinus sylvestris L., Querqus robur L., Acer platanoides L., Tilia cordata Mill., Betula pendula Roth., Fraxinus excelsior L., Populus tremula L. та Alnus glutinosa (L.) Gaerth. Спутниковые снимки отобраны для временного периода 2014-2016 гг. и объединены в безоблачные мозаики для трех сезонов: апрель-октябрь, лето, осень. После маскировки облаков для летней и осенней мозаик применен метод поканального отбора пикселей, которые имеют наибольшее значение индекса NDVI, тогда как для мозаики периода апрель-октябрь отбирали 1-й, 3-й квартили и медиану пикселей в соответствующем временном диапазоне. Всего для дешифрирования использовано 38 спектральных (каналы красного, ближнего и коротковолнового инфракрасного спектров, индекс NDVI, каналы преобразования ТCT) и неспектральных (географические координаты, высота над уровнем моря, топографическое положение) показателей.

Для дешифрирования распространения древостоев разного видового состава, а также древесных видов, которые доминируют в составе насаждений, на основании метода $k$ ближайших соседей $(k-\mathrm{NN})$ спрогнозированы значения сумм площадей сечений восьми наиболее представленных в лесном фонде области древесных видов. В исследовании использован алгоритм $k$-NN метода, адаптированный к платформе облачных вычислений Google Earth Engine. B качестве меры поиска ближайших coceдей выбрано Евклидово расстояние в пространстве

\footnotetext{
Миронюк Виктор Валентинович - член-корреспондент Лесной академии наук Украины, доцент кафедры таксации леса и лесного менеджмента, доктор сельскохозяйственных наук. Национальный университет биоресурсов и природопользования Украины, ул. Героев Обороны, 15, г. Киев, 03041, Украина. Тел.: +38-044-527-85-23. E-mail: victor.myroniuk@nubip.edu.ua ORCID: https://orcid.org/0000-0002-5961-300X
}

спектральных показателей спутниковых снимков Landsat и вспомогательной неспектральной информации. При этом применен алгоритм при $\mathrm{k}=1$. В результате исследования получены непрерывные попиксельные оценки сумм площадей сечений древостоев основных лесообразующих видов.

Установлено, что на территории области доминируют древостои, в которых насчитывается 3-5 составляющих древесных видов. При этом наименьшее видовое разнообразие свойственно соснякам, в составе лесных насаждений с преобладанием дуба, ясеня, клена и липы встречается большее количество сопутствующих видов. Указанные особенности влияют на точность дешифрирования, поскольку сложная пространственная структура лесных насаждений усложняет распознавание видового состава лесных насаждений. Используя полученные карты, установлено распространение основных лесообразующих древесных видов Сумской области. По оценкам сумм площадей сечений создана карта доминирующих древесных видов, что позволило сравнить в процентном соотношении площади насаждений с официальными данными учета лесов области. Базируясь на выполненных исследованиях, определена актуальность внедрения в инвентаризацию лесов Украины методов дистанционного зондирования Земли. При этом в работе сделан вывод о целесообразности применения временных рядов спутниковых снимков для дешифрирования видового состава лесных насаждений.

Ключевые слова: классификация; метод ближайших соседей; облачные вычисления; учет лесов; мониторинг; выборка; временной ряд; сумма площадей сечений.

\section{Mapping tree species composition of forest stands using Landsat seasonal mosaics and sample-based forest inventory}

\author{
V. Myroniuk'
}

Mapping tree species composition of forest stands using satellite imagery has great importance for assessment of forest recourses and their dynamics. The majority of modern publications have pointed on efficiency of tree species identification using time series of Earth observations in conjunction with sample-based forest inventory. We used time series of Landsat 8 OLI imagery to map tree species composition of forest stands, meanwhile regional-level sample-

Viktor Myroniuk - Corresponding Member of the Forestry Academy of Sciences of Ukraine, Associate Professor of the Department of Forest Mensuration and Forest Management. National University of Life and Environmental Sciences of Ukraine. 15, Heroiv Oborony st., Kyiv, 03041, Ukraine. Tel.: +38-044-527-85-23. E-mail: victor.myroniuk@nubip.edu.ua ORCID: https://orcid. org/0000-0002-5961-300X 
based inventory of forest in Sumy region (oblast) have been incorporated as source of reference data. Based on tree stems measurements on 333 circular sample plots, basal areas of eight forest forming tree species have been assessed (such as pine, oak, maple, lime, birch, ash, aspen and alder). The satellite images have been filtered for time frame of 2014-2016 and composed into cloud-free mosaics for three seasons: April-October, summer, autumn. After cloudiness were masked, for summer and autumn mosaics we applied maximum value composing approach using NDVI value, while for April-October mosaic we selected $1^{\text {st }}, 3^{\text {rd }}$ quartiles and median values of pixels in the specified time range. In total, 38 spectral (bands of red, near- and short-infrared spectra, NDVI and TCT bands) and non-spectral (geographical coordinates, elevation above see level, topographic position) features used for classification.

Forest stands of different tree species composition as well as dominant tree species has been mapped using $k$ nearest neighbor $(k-\mathrm{NN})$ imputation approach. In this paper, we explored the effectiveness of two technics: 1) mapping distribution of tree species within Sumy oblast; and 2) predicting tree species composition of forest stands. We have used Google Earth Engine implementation of $k$-NN algorithm to predict basal area for eight major tree species in the region. Euclidean distance has been applied as a measure of closeness to the nearest neighbor. We have used $k=1$ to search for neighbors in a space of spectral features of Landsat imagery and ancillary non-spectral information. As a result, continuous per-pixel distribution of basal areas of eight tree species has been predicted. Based on their contribution to total basal area, dominant tree species as well as stand composition at $30 \times 30 \mathrm{~m}$ pixel resolution have been derived.

It was found that forest stands composed by 3-5 tree species are common for Sumy oblast. At the same time, the lowest tree species diversity typically occurs in pine forests, while stands formed by oak, ash, maple and lime have a grater species richness. We believe these factors have significantly impacted accuracy of mapping in northern, central and southern parts of the study area, since more complex vertical structure of forest stands in southwest arises discrepancies in tree species identification. Based on predictive mapping, the distribution of major forest forming species of forests in Sumy oblast have been established. Using per-pixel estimates of basal areas and mapped dominant tree species, we have compared forest stands area with official forest inventory data. We have found some underestimation of remote sensing-based assessment of forested areas occupied by pine and oak stands. On the one hand we refer that to the map errors, on the other hands such inconsistencies may be result of classifying forests in operational forest management by desired species composition (not by their actual contribution to the total basal area). Nevertheless, derived results have pointed on necessity of satellitebased forest inventory in Ukraine which improve characterization of forest cover at landscape level through wall-to-wall mapping. We also concluded the effectiveness of tree species mapping using time series of Landsat satellite imagery and Google Earth Engine cloud platform.

Key words: classification; $k$ nearest neighbors; cloud computing; forest assessment; monitoring; sampling; time series; basal area. 